\title{
Note on Terminology and Language
}

The people of the Groote Eylandt archipelago do not have a name for themselves as a whole. Since this book is about language, I refer to people groups in terms of their language. I use "Anindilyakwa people" to refer to all fourteen clans of the Groote Eylandt archipelago that speak Anindilyakwa.

Though I use the word "clans," this concept is actually a European construction. From an Anindilyakwa perspective, society is based, first of all, on songs and songlines-that is, the songs and journeys of Creative Beings (also called "totems") over the landscape long ago (also called the "Dreaming"). These beings $c$ reated the spiritual identities of people b elonging to those places and determine their relationships with other people. The people who share a common spiritual identity and who are connected to the same songs, places, and Creative Beings make up what Europeans would consider a clan.

I often refer to individual Anindilyakwa people by (one of) their first names rather than by surname. Missionaries introduced surnames in the 1960s to satisfy the administrative requirements of the Commonwealth Government's Welfare Branch. The clans chose names connected to the Creative Beings and songlines. Lalara, for example, means "dangerous snakes" and was chosen as a s urname because of the king brown sn ake that $t$ raveled 
around Lalara country on the mainland in the Creation Period. Not only are these surnames a nachronistic when used for people before 1960, but since surnames follow clan lines, surnames are not useful for identifying individuals of the same clan.

In w riting this history of language negotiations and translations, I too use language. Like the missionaries, I participate in a national culture of English literacy that can silence those who do not have access. All my interviews with A nindilyakwa people were c onducted in English, s ometimes w ith a friend or relative assisting where we had trouble understanding one another. Moreover, I am using written English to convey this history. History is shared through common language, a nd by u sing w ritten English I c ommunicate with a particular language community-you English-readers-as opposed to any o ther language community. A lthough I i nclude passages in A nindilyakwa, I c annot tell a n A nindilyakwa story, a nd to some extent, I e xclude non-English-readers by telling the story in this way. Furthermore, this history of language engagements will be lopsided since I myself am a member of the community of English-speakers and -writers. My writing risks perpetuating the very colonizing ideologies I hope to uncover-that is, the assumption that English must be the language of public discourse, of authority, and of the intellect. I hope this will not be the case. Academic history writing has limitations, and its use of language to communicate only to a select audience is one such limit. But academic history is not the only form of history, and I hope my work will be of interest to Anindilyakwa-speakers; it will be theirs to translate, a ssess, a nd r einterpret in their own language a ccording to their own historical practices. 